\title{
The relation of body mass index and smoking with liver function
}

\author{
Safiya A. Salih*, Nadwa A.J. Mahmood** \\ * Clinical Biochemistry unit, Al-Batool Teaching hospital, Mosul, ** Department of Biochemistry, College of \\ Medicine, University of Mosul, Mosul, Iraq. \\ Correspondence: Safiya A. Salih. osamasufyan@yahoo.com.
}

(Ann Coll Med Mosul 2018; 40 (2): 48-53).

Received: $5^{\text {th }}$ Jun. 2018; Accepted: $28^{\text {th }}$ Oct. 2018.

\section{ABSTRACT}

Objective: To assess the effect of BMI and smoking on liver function.

Materials and methods: Case- series study was conducted to assess the relation between liver function tests(aspartate amino transferace (AST), alnine amino transferace (ALT), Alkaline phosphatase, lactate dehydrogenase (LDH), protein albumin and billirubin), and BMI and smoking in 1020 apparently healthy persons using commercially available kit.

Results: Significant direct relationship between liver enzymes activities, serum total protein and globulin and BMI were observed. Albumin, bilirubin and $A / G$ ratio values were decreased by increasing BMI. Significant relation was observed between the mean activity of (AST) and cigarette smoking. Significant inverse relationship was observed between mean values of total protein, albumin, globulin and bilirubin with cigarette smoking

Conclusion: serum enzymes activities of (AST, ALT, ALP and LDH), total protein and globulin had direct positive relationship with $\mathrm{BMI}$, while albumin, $\mathrm{A} / \mathrm{G}$ ratio and total bilirubin had inverse relationship. Smoking has a significant effect of on AST, total protein, albumin, globulin and total bilirubin, while doesn't affect ALT, ALP, and LDH.

Keywords: Liver function tests and BMI, liver function tests and smoking.

\section{تأثير معامل كتلة الجسم والتدخين على وظائف الكبد}

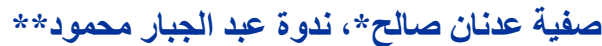

$$
\begin{aligned}
& \text { * وحدة الكيمياء السريرية، مستثفى البتول التعليمي، الموصل، ثُ نب فرع الكيمياء، كلية الطب، جامعة الموصل ، العراق }
\end{aligned}
$$

$$
\text { الهُف: لنقييم تأثير معامل كتلة الجسم و التناخين على وظائف الكبد. }
$$

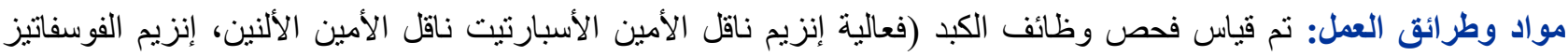

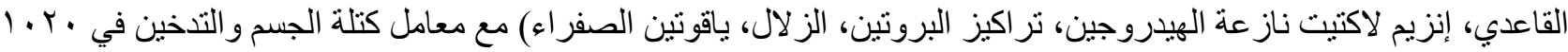

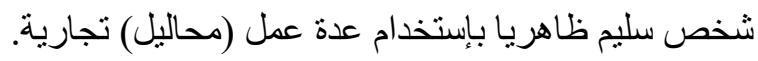

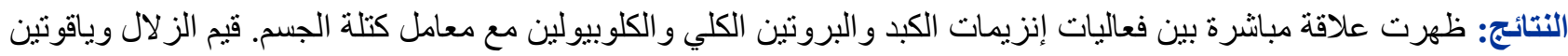

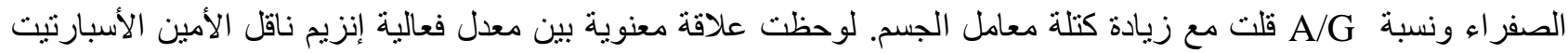

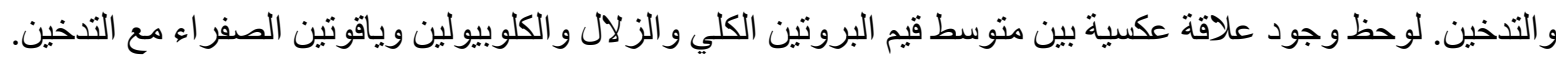

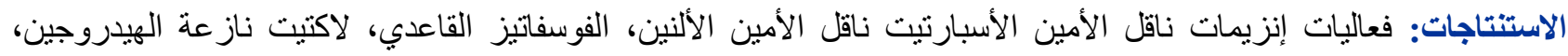

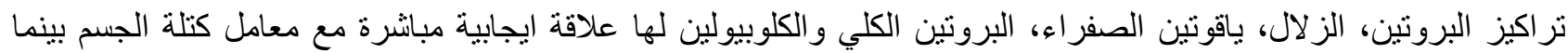

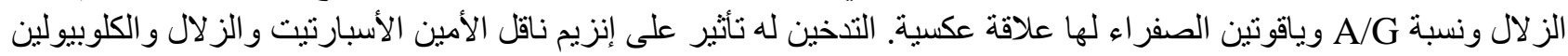

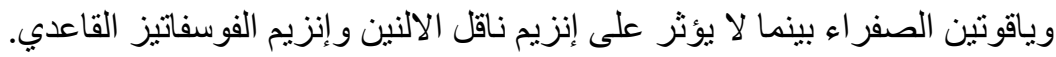

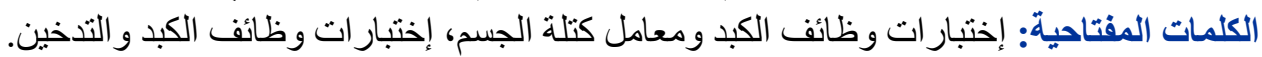




\section{INTRODUCTION}

E nzymes pattern in liver disease includes the assay of aminotransferases (AST, ALT), alkaline phosphatase (ALP) and lactate dehydrogenase (LDH) activity. AST is found primarily in the heart, liver, skeletal muscle, and kidney, whereas ALT is found primarily in the liver and kidney with a lesser amounts in heart and skeletal muscle. ${ }^{1}$ The highest activities of these enzymes are caused by any acute liver damage. ${ }^{2}$ ALP enzyme is involved in the metabolic transport across cell membranes. The response of the liver to any form of biliary tree obstruction is to synthesize more $\mathrm{ALP}^{3}{ }^{3} \mathrm{LDH}$, as it involves in glucose metabolism, is present in all living cells. Elevations are especially high in toxic hepatitis with jaundice. ${ }^{4}$ Serum albumin concentration is widely regarded as an index of hepatic synthetic function. Extreme hypergloblinaemia is characteristic of chronic active hepatitis. ${ }^{1}$ Serum bilirubin, in the liver, is bound to ligandin ( $Y$ protein) and it is actively transported to the smooth endoplasmic reticulum where it is conjugated with glucuronate, a process catalysed by uridyl diphosphoglucuronyl transferase (UDPGT) Then it is secreted by active processes into the bile canaliculi. ${ }^{5}$ Our study aims to assess the effect of body mass index and smoking on these liver functions tests.

\section{MATERIALS AND METHODS}

Subject: the 1020 participated subjects were apparently healthy individuals, 650 males and 370 females, age range 18-73 years ( mean \pm SD $34 \pm$ 10.8). All subjects were medically examined for signs of liver diseases and informations were obtained regarding their height, weight and smoking whatever the duration and number of cigarette smoking at the time of examination, and the body mass index (BMI) was calculated as weight $\mathrm{kg} / \mathrm{height} \mathrm{m}^{2}$. BMI less than $18.5 \mathrm{~kg} / \mathrm{m}^{2}$ is regarded as underweight, $18.5-24.9 \mathrm{~kg} / \mathrm{m}^{2}$ normal weight, $25-29.9 \mathrm{~kg} / \mathrm{m}^{2}$ over weight, $30-39.9 \mathrm{~kg} / \mathrm{m}^{2}$ obese, and more than $40 \mathrm{~kg} / \mathrm{m}^{2}$ is regarded as gross obesity. ${ }^{6}$ Fasting blood samples were obtained between 8:30 and 10:30 a.m. Samples were analyzed directly for liver enzymes or stored at $-20^{\circ} \mathrm{C}$ until other analysis were done. All biochemical analyses were performed at the Department of Biochemistry, Mosul College of Medicine, Iraq. The reagents kits for serum AST,
ALT and LDH measurements were purchased from Randox, (UK), for serum ALP and serum total protein measurements from Biomerienx, (France), for serum albumin measurement from Bicon, (Germany) and for serum direct and total bilirubin measurements from Biomaghreb (Maghreb).

Statistical analysis: Standard statistical methods were used to determine the mean, standard deviation (SD), standard error (SE), coefficient of variation $(\mathrm{CV})$ and range (minimum-maximum). $\mathrm{Z}$ test was used to compare the results for various biochemical parameters among subjects in different groups. Duncans test was used to identify group (S) responsible for statistical difference through comparison.

\section{RESULTS}

The study group was subclassified into 5 subgroups according to age and sex as presented in Table 1.

Relationship between the biochemical liver function tests and body mass index (BMI): the BMI was into 5 subgroups, Table 2.

Liver enzymes relation to BMI: Table 3 shows the results of liver enzymes presented as mean \pm SE according to BMI. Statistical $F$ test revealed significant relationship between the mean enzymes activities and $\mathrm{BMI}(\mathrm{F}=40.9, \quad \mathrm{P}<0.001)$ for $\mathrm{AST}$, ( $F=22.6, P<0.001)$ for $A L T,(F=13.1, P<0.001)$ for ALP and $(F=10.9, P<0.001)$ for LDH. Duncan's test also revealed significant relation of mean enzymes activities with BMI. The mean values of enzymes activity were directly proportional to BMI.

Serum total protein, albumin, globulin and A/G ratio relation to BMI: Table 4 shows the results of serum total protein, albumin, globulin and $A / G$ ratio presented as mean $\pm S E$ according to $B M I$. Statistical $F$ test revealed a significant relation between total protein albumin, globulin and $A / G$ ratio with $\mathrm{BMI}(\mathrm{F}=3.73, \mathrm{P}=0.005)$ for total protein, $(\mathrm{F}=4.05, \mathrm{P}=0.003)$ for albumin $(\mathrm{F}=2.31, \mathrm{P}=0.005)$ for globulin, $(F=2.44, P=0.045)$ for $A / G$ ratio. Duncan's test revealed also significant relation between the above parameters and the BMI. The mean values of total protein and globulin were increased by increasing BMI, while those of albumin and $A / G$ ratio were decreased by increasing BMI. 
Serum indirect, direct and total bilirubin relation to BMI: Table $\mathbf{5}$ shows the results of indirect, direct and total bilirubin according to BMI. Statistical $F$ test revealed significant inverse relation with $\mathrm{BMI}(\mathrm{F}=4.56 \mathrm{P}=0.001)$ for total $(\mathrm{F}=6.3$ $P=0.003)$ for the direct and $(F=3.5 P=0.001)$ for the indirect bilirubin. Duncan's test also revealed significant inverse relation between total, direct and indirect bilirubin with the BMI.

Relation of smoking to the biochemical liver function tests: since there was no female smokers in the study subjects, the effect of smoking on the different biochemical liver function tests was studied in male only. Table 6 shows the relation of smoking on the studied parameters. It is apparent that there was significant increase in AST activity among smokers than that of non-smokers with $P$ values of 0.006 and 0.0001 respectively. A significant inverse relationship was noticed between total protein, albumin and globulin with cigarette smoking with $p$ value 0.0001 for total protein and albumin and $P$ value 0.02 for globulin. Another inverse significant relationship was observed between cigarette smoking and the concentration of total bilirubin and direct bilirubin with $\mathrm{P}$-value $<0.001$.
Table 1. Distribution of subjects according to age and sex.

\begin{tabular}{cccc}
\hline $\begin{array}{c}\text { Age } \\
\text { (years) }\end{array}$ & Sex & Number & $\%$ \\
\hline \multirow{2}{*}{$\mathbf{1 8 - 2 5}$} & $\mathrm{M}$ & 156 & 15.3 \\
& $\mathrm{~F}$ & 60 & 5.9 \\
$\mathbf{2 5 - 3 5}$ & $\mathrm{M}$ & 242 & 23.7 \\
& $\mathrm{~F}$ & 120 & 11.7 \\
$\mathbf{3 5 - 4 5}$ & $\mathrm{M}$ & 175 & 17.2 \\
& $\mathrm{~F}$ & 114 & 11.2 \\
$\mathbf{4 5 - 5 5}$ & $\mathrm{M}$ & 46 & 4.5 \\
& $\mathrm{~F}$ & 40 & 3.9 \\
$\mathbf{5 5 - 6 5}$ & $\mathrm{M}$ & 31 & 3.1 \\
Total & $\mathrm{F}$ & 36 & 3.5 \\
\hline
\end{tabular}

Table 2. The study groups according to body mass index (BMI).

\begin{tabular}{lccc}
\hline $\begin{array}{c}\text { Groups } \\
\text { according to } \\
\text { BMl }\left(\mathrm{kg} / \mathrm{m}^{2}\right)\end{array}$ & No. & $\%$ & $\begin{array}{c}\text { BMI }\left(\mathrm{kg} / \mathrm{m}^{2}\right) \\
\text { Mean } \pm \text { SD }\end{array}$ \\
\hline$<18.5$ & 7 & 0.7 & $18 \pm 0.3$ \\
\hline $18.5-24.9$ & 484 & 47.4 & $22.9 \pm 1.45$ \\
\hline $25-29.9$ & 414 & 40.6 & $26.5 \pm 1.35$ \\
$30-39.9$ & 109 & 10.7 & $31.5 \pm 1.5$ \\
$>40$ & 6 & 0.6 & $36.5 \pm 1.0$ \\
\hline Total & 1020 & 100.0 & $25.33 \pm 3.23$ \\
\hline
\end{tabular}

Table 3. Comparison of the mean liver enzymes activities according to BMI using Duncan's test (data are presented as mean + SE)

\begin{tabular}{lccccc}
\hline $\begin{array}{l}\mathrm{BMI} \\
\mathrm{Kg} / \mathrm{m}^{2}\end{array}$ & No. & $\begin{array}{c}\text { AST } \\
(\mathbf{U} / \mathrm{L})\end{array}$ & $\begin{array}{c}\text { ALT } \\
(\mathrm{U} / \mathrm{L})\end{array}$ & $\begin{array}{c}\text { ALP } \\
(\mathrm{U} / \mathrm{L})\end{array}$ & $\begin{array}{c}\text { LDH } \\
(\mathrm{U} / \mathrm{L})\end{array}$ \\
\hline$<18.5$ & 7 & $12.4 \pm 1.8 \mathrm{ab}$ & $8.9 \pm 1.1 \mathrm{a}$ & $38.2 \pm 5.9 \mathrm{a}$ & $98.6 \pm 4.5 \mathrm{a}$ \\
$18.5-24.9$ & 473 & $9.9 \pm 0.2 \mathrm{a}^{*}$ & $9.9 \pm 0.2 \mathrm{a}$ & $52.8 \pm 0.8 \mathrm{~b}$ & $122.8 \pm 1.5 \mathrm{~b}$ \\
\hline $25-29.9$ & 402 & $11.9 \pm 0.2 \mathrm{ab}$ & $10.9 \pm 0.2 \mathrm{ab}$ & $56.8 \pm 0.9 \mathrm{~b}$ & $131.9 \pm 1.8 \mathrm{~b}$ \\
$30-39.9$ & 109 & $14.3 \pm 0.4 \mathrm{~b}$ & $13.4 \pm 0.4 \mathrm{bc}$ & $64.5 \pm 2.1 \mathrm{bc}$ & $142.6 \pm 3.2 \mathrm{~b}$ \\
$>40$ & 6 & $18.0 \pm 0.7 \mathrm{c}$ & $15.5 \pm 1.1 \mathrm{c}$ & $74.9 \pm 5.0 \mathrm{c}$ & $141.5 \pm 3.4 \mathrm{~b}$ \\
\hline Total & 997 & $11.26 \pm 0.1$ & $10.7 \pm 0.1$ & $55.8 \pm 0.6$ & $128.6 \pm 1.2$ \\
\hline
\end{tabular}

* Different letters vertically mean significant difference at $P \leq 0.05$. In vertical column, different letters (a,ab,b,and $c)$ more significant than the same letters $(a, b, b, b$,

Table 4. Comparison of the mean values of serum total protein, albumin, globulin and A/G ratio according to BMI (data are presented as mean $\pm \mathrm{SE}$ ).

\begin{tabular}{lccccc}
\hline $\begin{array}{c}\text { BMI } \\
\left(\mathrm{Kg} / \mathbf{m}^{2}\right)\end{array}$ & No. & $\begin{array}{c}\text { Total protein } \\
(\mathbf{g} / \mathbf{L})\end{array}$ & $\begin{array}{c}\text { Albumin } \\
(\mathbf{g} / \mathbf{L})\end{array}$ & $\begin{array}{c}\text { globuline } \\
(\mathbf{g} / \mathbf{L})\end{array}$ & A/G ratio \\
\hline$<18.5$ & 7 & $71.6 \pm 2.9 \mathrm{a}^{*}$ & $43.1 \pm 1.0 \mathrm{~b}$ & $27.8 \pm 1.8 \mathrm{a}$ & $1.55 \pm 0.7 \mathrm{~b}$ \\
$18.5-24.9$ & 484 & $73.8 \pm 0.3 \mathrm{~b}$ & $42.6 \pm 0.2 \mathrm{ab}$ & $31.1 \pm 0.2 \mathrm{~b}$ & $1.38 \pm 0.01 \mathrm{a}$ \\
\hline $25-29.9$ & 414 & $72.6 \pm 0.3 \mathrm{ab}$ & $42.1 \pm 0.2 \mathrm{ab}$ & $30.5 \pm 0.2 \mathrm{ab}$ & $1.4 \pm 0.01 \mathrm{a}$ \\
$30-39.9$ & 109 & $73.3 \pm 0.6 \mathrm{~b}$ & $42.3 \pm 0.4 \mathrm{ab}$ & $31.0 \pm 0.4 \mathrm{~b}$ & $1.42 \pm 0.02 \mathrm{ab}$ \\
$>40$ & 6 & $73.2 \pm 3.1 \mathrm{~b}$ & $41.0 \pm 1.5 \mathrm{a}$ & $32.0 \pm 2.2 \mathrm{~b}$ & $1.35 \pm 0.08 \mathrm{a}$ \\
\hline Total & 1020 & $73.4 \pm 0.2$ & $42.5 \pm 0.1$ & $30.8 \pm 0.1$ & $1.39 \pm 0.06$ \\
\hline
\end{tabular}

${ }^{*}$ Different letter vertically mean significant difference at $p \leq 0.05$ 
Table 5. Comparison of the mean values of indirect, direct and total bilirubin, according to BMl using Duncan's test (data are presented as mean $\pm \mathrm{SE}$ ).

\begin{tabular}{lcccc}
\hline \multicolumn{1}{c}{$\begin{array}{c}\text { BMI } \\
\left(\mathrm{Kg} / \mathrm{m}^{2}\right)\end{array}$} & No. & Total & Bilirubin $(\mu \mathrm{mol} / \mathrm{L})$ \\
\cline { 3 - 5 } & & $10.5 \pm 1.9 \mathrm{c}$ & $1.9 \pm 0.4 \mathrm{c}$ & Indirect \\
\hline$<18.5$ & 7 & $9.4 \pm 0.2 \mathrm{~b}$ & $1.6 \pm 0.04 \mathrm{~b}$ & $7.6 \pm 1.6 \mathrm{c}$ \\
$18.5-24.9$ & 484 & $9.2 \pm 0.2 \mathrm{~b}$ & $1.2 \pm 0.04 \mathrm{ab}$ & $8.0 \pm 0.1 \mathrm{~b}$ \\
$25-29.9$ & 414 & $8.5 \pm 0.4 \mathrm{bb}$ & $1.2 \pm 0.08 \mathrm{ab}$ & $7.3 \pm 0.3 \mathrm{a}$ \\
$30-39.9$ & 109 & $7.8 \pm 1.2 \mathrm{a}^{*}$ & $0.8 \pm 0.3 \mathrm{a}$ & $7.0 \pm 0.8 \mathrm{a}$ \\
$>40$ & 6 & $9.1 \pm 0.1$ & $1.4 \pm 0.03$ & $7.7 \pm 0.09$ \\
\hline
\end{tabular}

*Different letters vertically mean significant difference at $p \leq 0.05$.

Table 6. Comparison between different parameters of liver function tests in nonsmokers and smokers using Z test (data are presented as mean $\pm \mathrm{SD}$ ).

\begin{tabular}{lcccccc}
\hline \multicolumn{1}{c}{ Parameter } & Nonsmoker & No. & Smoker & No. & Z & P \\
\hline AST $(\mathrm{U} / \mathrm{L})$ & $10.7 \pm 4.1$ & 369 & $11.5 \pm 3.8$ & 264 & 2.73 & $* *$ \\
ALT $(\mathrm{U} / \mathrm{L})$ & $10.6 \pm 4.1$ & 369 & $11.1 \pm 4.1$ & 264 & 1.30 & NS \\
ALP $(\mathrm{U} / \mathrm{L})$ & $55.2 \pm 19.8$ & 369 & $56.3 \pm 18.6$ & 264 & 0.82 & NS \\
LDH $(\mathrm{U} / \mathrm{L})$ & $130.4 \pm 33.9$ & 369 & $132.8 \pm 34.5$ & 264 & 0.72 & $\mathrm{NS}$ \\
\hline Total protein $(\mathrm{g} / \mathrm{L})$ & $75.2 \pm 5.8$ & 377 & $72.6 \pm 6.3$ & 273 & 5.03 & $* * *$ \\
Albumin $(\mathrm{g} / \mathrm{L})$ & $43.7 \pm 3.6$ & 377 & $42.2 \pm 4.2$ & 273 & 4.74 & $* * *$ \\
Globulin $(\mathrm{g} / \mathrm{L})$ & $31.2 \pm 4.1$ & 377 & $30.5 \pm 3.9$ & 273 & 2.31 & $*$ \\
Total bilirubin $(\mu \mathrm{mol} / \mathrm{L})$ & $9.1 \pm 2.5$ & 377 & $7.4 \pm 2.5$ & 273 & 6.76 & $* * *$ \\
Direct bilirubin $(\mu \mathrm{mol} / \mathrm{L})$ & $1.7 \pm 0.9$ & 377 & $1.1 \pm 0.7$ & 273 & 5.48 & $* * *$ \\
\hline
\end{tabular}

NS: not significant, ${ }^{*}$ : mildly significant at $p \leq 0.05,{ }^{* *}$ : moderately significant $p \leq 0.01,{ }^{* * *}$ : highly significant $p \leq 0.001$.

\section{DISCUSSION}

The current study showed that all liver enzymes had significant relationship with BMI. The mean enzyme activity was directly proportional to BMI. Another study of 21000 subjects attending the BUPA medical center in London reported significant relation of liver enzymes with $\mathrm{BMI}^{7}$ Comparable results were reported elsewhere. ${ }^{8,9,10}$ Predicted increased fatty liver associated with BMI lead to increase hepatic enzymes level, also most of these enzymes present in other organs like skeletal muscles, so increased BMI leads to increase these enzymes. A study of 528 obese subjects in Belgium reported significant higher mean serum liver enzyme activities (AST, ALT and ALP) but remained within laboratory reference values. ${ }^{11}$ However, no significant relation of LDH with BMI was found in females by other report from working group which measured the reference intervals for serum enzymes. ${ }^{12}$

In the current study, the mean values of serum albumin decreased while that of globulin increased along with increasing $\mathrm{BMI}$; this is in agreement with the results published by Wingerd and
Sponzilli ${ }^{13}$ who explained the increase of globulin concentration by the fact that the concentration of lipoproteins is expected to increase with weight. The effect on albumin is difficult to rationalize, and if increasing weight usually leads to higher serum lipid this might cause slight systematic changes. ${ }^{13}$

Serum indirect, direct and total bilirubin in the current study showed significant inverse relationship with BMI. Bilirubin consumption occur in obesity which associated with increase inflammation and oxidative stress and bilirubin presenting antioxidant and antiinflammatory. ${ }^{14}$

The current study showed that smoking associated with an increase in enzymes activity of AST with $(p=0.01)$ which agreed with other study ${ }^{7}$ and this may be attributed to the fact that cigarette smoke contains a large variety of compounds including many oxidants and free radicals that are capable of causing a pro- oxidant/ antioxidant imbalance in the blood and tissues of smokers, so hepatocellular damage leads to release of enzymes into the circulation. ${ }^{15}$ No significant relation of smoking was found on the enzyme activity of ALT, ALP and LDH and this may be 
related to duration, amount and type of smoking. Wannamethee and Sharper (2010) also not advocated the relation of smoking with the activity of these enzymes. ${ }^{16}$ There was significant relation of smoking with the decreasing level of total protein, albumin and globulin among smokers with $p<0.001$ for both total protein and albumin and $p<0.05$ for globulin. Similar results were reported by others. ${ }^{13}$ These findings could be attributed to the suggestion of $\mathrm{Holt}^{17}, 1973$ and $\mathrm{Green}^{3}$, 2002) that smoking may result in the impairment of response and immuno surveillance and this may contribute to the increased prevalence of chronic bronchitis and carcinoma among smokers.

The current study also showed a decrease in total and direct bilirubin level among smokers with $\mathrm{p}<0.001$ which in agreement with a study by Van Hoydonck and his coworkers, 2001. ${ }^{18}$ Bilirubin, which is a bile pigment is generally regarded as waste product of haem catabolism. However, it has been suggested that bilirubin may have an important role as endogenous antioxidant and is destroyed by reactive oxygen species. ${ }^{19}$ The observed low bilirubin concentration might be the result of an overconsumption of bilirubin by free radical species related to cigarette smoke. ${ }^{17}$ Another possible mechanism which can determine serum bilirubin concentration is hepatic UDPGT activity. ${ }^{20}$ Cigarette smoke is known to induce UDPGT activity by which hepatic UDPGT is inversely related to serum bilirubin concentration. ${ }^{21}$

\section{CONCLUSION}

Increased BMI and obesity had adverse effect on liver enzymes as AST, ALT, ALP, LDH, total protein and globulin were increased in direct positive relationship with $\mathrm{BMI}$, while albumin, $\mathrm{A} / \mathrm{G}$ ratio and bilirubin had inverse relationship with BMI. Smoking also adversely affect liver activities in a significant increase of AST, total protein, albumin, globulin and total and direct bilirubin.

Acknowledgement: Authors gratefully thank the staff of the Department of Biochemistry, College of Medicine and the staff of Blood Transfusion Center in Mosul for their help in facilitating this work.

\section{REFERENCES}

1. Weisiger RA. Laboratory test in liver disease and approach to the patient with abnormal tests. Sited in
Powel DW, Drazen JM, Gill GN, Griggs RC, Kokko TP, Mandell GL, Schafer Al (eds), Cecil Text Book of Medicine, 2000. $21^{\text {st }}$ ed, Saunders, Philadelphia, USA. pp. $775-780$.

2. Munteann M, Messous D, Thabut D, Bismut FI, Jouys $M$, Massard J. Intra individual fasting versus post prandial variation of biochemical markers of liver fibrosis (fibrotest) and activity (Acti test). 2004. website. http://www.comparative-hepatology.com.

3. Green RM, Flamm S. American Gastroenterological Association (AGA) technical review on the evaluation of liver chemistry tests. Gastroenterology 2002;123 (4):1469-1495

4. Sherwood P, Lyburn I, Brown S, Ryder S. How are abnormal results for liver function tests dealt with in primary care? Audit of yield and impact. B.M.J. 2001;322: 276-278.

5. Wolkoff AW. Bilirubin metabolism and hyperbilirubinaemia. Sited in Braunwald E, Fauci AS, Kasper, Hauser S, Longo D and Jameson JL. Harrison's principles of internal medicine. 2005.16 ${ }^{\text {th }}$ ed. McGrawHill, Newyork, USA. pp: 1817-1821.

6. Haslett C, Chilvers ER, Boon NA, Colledge NR, Hunter JA. Davidson's Principles and Practice of Medicine. 2002. $19^{\text {th }}$ ed. Churchill, Livingstone, philadelphia, USA. p. 298.

7. Robinson D, Whitehead TP. Effect of body mass and other factors on serum liver enzyme levels in men attending for well population screening. Ann. Clin. Biochem. 1989;26: 393-400.

8. Hetland G, Holme I, Stromme JH. Co-variaion of alanine aminotransferase level with relative weight in blood donars. Scand. J. Clin. Lab. Invest. 1992;52(1): 51-55.

9. Leino A, Impivaara O, Irjala K, Maki J, Peltola O, Jarvis A. Health-based reference intervals for ALAT, ASAT, GT in serum measured according to the recommendations of the European Committee for Clinical Laboratory Standards (ECCLS). Scand. J. Clin. Lab. Invest. 1995;55 (3): 243-250.

10. Piton A, Poynard T, Imbert-Bismut F, Khalil L, Delattre J, Pelissie Sansonetti N, Opolon P. Factors associated with serum alanine transaminase activity in healthy subjects: Consequences for the definition of normal values, for selection of blood donars and for patients with chronic hepatitis C. Multivirc group. Hepatology. 1998;27 (5): 1213-1219.

11. Luyckx FH, Desaive C, Thiry A, Dewe W, Scheen AJ, Gielen J E, Lefebvre. Liver abnormality in severely obese subjects: Effect of drastic weight loss after gastroplasty. Int. J. obesity. 1998;22 (3): 222-226.

12. Land K, Rustad P, Steen H, Stromme J, Theodorsen $L$, Urdal P. Suggested reference intervals for 8 serum enzymes on data from the NORIP database. Report from working group on enzymes established by the Norwegian Association of Clinical Chemistry. 2003. website http://www.furst.no/norip.

13. Wingerd J, Sponzilli EE. Concentration of serum protein fractions: Effects of age, weight, smoking, tonsillectomy and other factors. Clin. Chem. 1977;23 (7): 1310-1317.

14. Berk PD, Martin JF, Blaschke TF, Schorchmidt BF, Plotz PH. Unconjugated hyperbilirubinemia: Physiologic 
evaluation and experimental approaches to therapy. Ann. Intern. Med. 1975;82: 552-570.

15. Chan-Yeung M, Ferreira P, Frohlich J, Schulzer $M$, Tan F. The effect of age, smoking and alcohol on routine laboratory tests. Am. J. Clin. Pathol. 1981;75: 320-326.

16. Wannamethee SG, Sharper AG. Cigrate smoking and serum liver enzyme. Annals of clinical biochemistry. Int.J.of Lab. Med. 2010;47:321-326.

17. Holt PG, Thomas WR, Keast D. Smoking and immunity.Lancet. 1973;1: 1316.

18. Van Hoydonck PGA, Temme EHM, Schouten EG. Serum bilirubin concentration in a Belgian population: The association with smoking status and type of cigarettes. Int. J. of Epidemiology. 2001;30: 1465-1472.
19. Hidalgo FJ, Zamora R, Dillard CJ, Tappel AL. Can serum bilirubin be an index of invivo oxidative stress? Med. Hypothesis. 1990;33: 207-211. [Abstract]

20. Murray RK, Granner DK, Mayes PA, Rodwell VW. Harper's Biochemistry. 2000. 25 ${ }^{\text {th }}$ ed. Appleton and Lange, N. Y. pp 276-278, 368-373.

21. Villard $\mathrm{PH}$, Herber R, Seree EM, Attolini L, Magdalon $\mathrm{J}$, Lacarelle B. Effect of cigarette smoke on UDPglucuronosyl transferase activity and cytochrome P450 content in liver, lung and kidney microsomes. J. Pharmacol. 1998;82: 74-79. 